Yesterday's Monsters 



\title{
Yesterday's Monsters
}

\author{
THE MANSON FAMILY CASES \\ AND THE ILLUSION OF PAROLE
}

Hadar Aviram

甲

UNIVERSITY OF CALIFORNIA PRESS 
University of California Press, one of the most distinguished university presses in the United States, enriches lives around the world by advancing scholarship in the humanities, social sciences, and natural sciences. Its activities are supported by the UC Press Foundation and by philanthropic contributions from individuals and institutions. For more information, visit www.ucpress.edu.

University of California Press

Oakland, California

(C) 2020 by The Regents of the University of California

Cataloging-in-Publication Data is on file at the Library of Congress.

ISBN 978-0-520-29154-6 (cloth : alk. paper)

ISBN 978-0-520-29155-3 (pbk. : alk. paper)

ISBN 978-0-520-96528-7 (ebook)

Manufactured in the United States of America

$\begin{array}{lllllllll}28 & 27 & 26 & 25 & 24 & 23 & 22 & 21 & 20\end{array}$

$\begin{array}{llllllllll}\text { IO } & 9 & 8 & 7 & 6 & 5 & 4 & 3 & 2 & \text { I }\end{array}$ 
To my son, Río,

may you grow up in a world of nonviolence, compassion, and forgiveness 
